\title{
$\widehat{A}$ Madridge \\ madridge Journal of Case Reports and Studies
}

Interconnecting Scientific World

Open Access

\section{What does Dermoscopy Say about Glomus Tumors?}

\author{
Younes Barbach*, Mohammed Chaouche, Abdellah Dah Cherif, Sara Elloudi, Hanane Baybay and Fatima Zahra Mernissi \\ Department of Dermatology, Hassan II University Hospital, Morocco
}

\section{Article Info}

\author{
*Corresponding author: \\ Younes Barbach \\ Doctor \\ Department of Dermatology \\ Hassan II University Hospital \\ Morocco \\ E-mail: dr.younes2011@gmail.com
}

Received: March 20, 2019

Accepted: March 27, 2019

Published: April 2, 2019

Citation: Barbach $Y$, Chaouche M, Cherif AD, Elloudi S, Baybay H, Mernissi FZ. What does dermoscopy say about glomus tumors? Madridge J Case Rep Stud. 2019; 3(1): 132-133. doi: 10.18689/mjcrs-1000133

Copyright: (c) 2019 The Author(s). This work is licensed under a Creative Commons Attribution 4.0 International License, which permits unrestricted use, distribution, and reproduction in any medium, provided the original work is properly cited.

Published by Madridge Publishers

\section{Image in Medicine}

Glomus tumor is an uncommon tumor arising from the glomus cells. They are usually noted in subungal locations. They are extremely painful to pressure, exposure to cold, and even to touch [1]. The pain increases on application of pressure with the tip of a pencil over the precise area (Love's sign) [2].

Treatment of choice for glomus tumor is surgical excision. Also, sclerotherapy as well as laser therapy with $\mathrm{CO}_{2}$, pulsed dye and $\mathrm{Nd}$ : YAG can be employed. Recurrences are noted due to local invasion of tumor [3].

Since the diagnosis of glomus tumors remains difficult to remember based on clinical criteria, dermoscopy can help. The dermoscopic finding previously reported in the literature include a discrete linear vascular structure on the nail plate and numerous telangiectasias ramified on the nail bed and matrix [4], an altered pigmentary network and a pinkish hue [5]. However, these results are not universal. In a recent report, instead of the pinkish hue, a homogeneous white discoloration of the nail plate was observed [6]. Thus, dermoscopy can be helpful in screening glomus tumor, however, the role of histopathological examination remains essential to make the diagnosis.

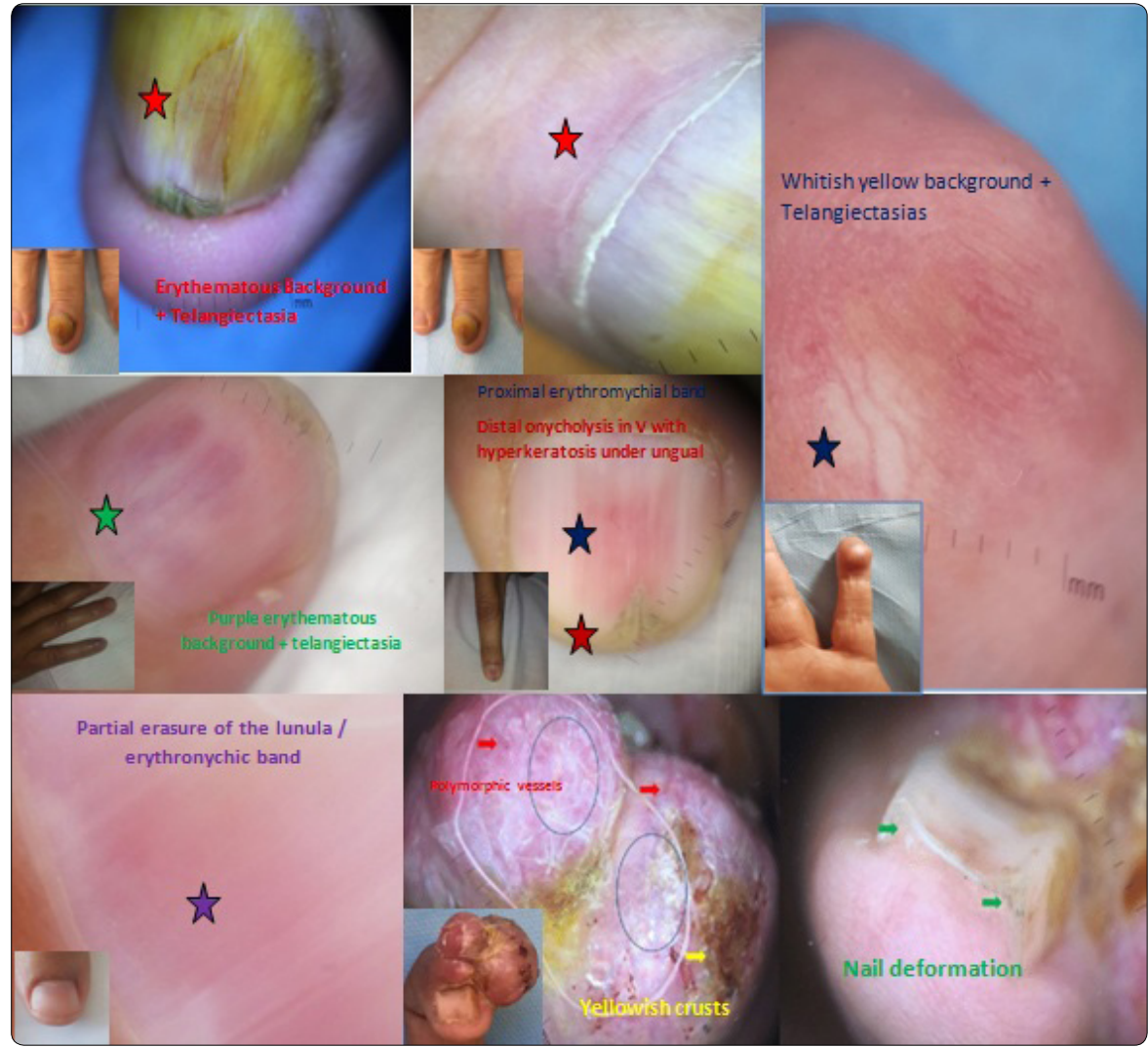

Figure 1. Dermoscopy panorama of glomus tumors collected from our case series. 
We report a dermoscopy overview of glomus tumors collected from our case series [Figure 1]. Various dermoscopic signs were objectified, notably proximal erythronychic bands, distal onycholysis, an erythematous or a yellowish white background, polymorphic vessels, tumor nail deformity, and telagiectasia. The most found signs were the erythematous background and telangiectasia.

The dermoscopic differentials include hemangioma, angiokeratoma, and subungual hemorrhage. The dermoscopic hallmark of hemangioma is the presence of numerous, round-to-oval areas with a reddish or red-bluish coloration. These red lacunas (red lagoons) are pathognomonic for hemangiomas. Angiokeratoma can also have these red lacunae, alongside white to yellow keratotic structures and a whitish veil. Subungual hemorrhage is characterized by the presence of jet-black pigmentation apart from the red lacuna.

\section{References}

1. Khandpur S, Ramam M. Skin tumours. J Cutan Aesthet Surg. 2012; 5(3): 159-162. doi: 10.4103/0974-2077.101368

2. Murthy PS, Rajagopal R, Kar PK, Grover S. Two cases of subungual glomus tumor. Indian J Dermatol Venereol Leprol. 2006; 72(1): 47-49.

3. Sheth S, Lai CK, Dry S, Binder S, Fishbein MC. Benign vascular tumors and tumor-like proliferations. Semin Diagn Pathol. 2008; 25(1): 1-16.

4. Maehara Lde S, Ohe EM, Enokihara MY, Michalany NS, Yamada S, Hirata $\mathrm{SH}$. Diagnosis of glomus tumor by nail bed and matrix dermoscopy. An Bras Dermatol. 2010; 85(2): 236-238.

5. Thatte SS, Chikhalkar SB, Khopkar US. 'Pink glow': A new sign for the diagnosis of glomus tumor on ultraviolet light dermoscopy. Indian Dermatol Online J. 2015; 6: S21-23. doi: 10.4103/2229-5178.171041

6. Mutsaers ER, Genders R, van Es N, Kukutsch N. Dermoscopy of glomus tumor: More white than pink. J Am Acad Dermatol. 2016; 75(1): e17-e18. doi: 10.1016/j.jaad.2016.01.049 